\title{
Cornukaempferia argentifolia (Zingiberaceae), a new species from northern Thailand
}

\author{
Saensouk P. ${ }^{1}$, Saensouk S. ${ }^{2 \star} \&$ T. Boonma ${ }^{3}$ \\ ${ }^{1}$ Plant and Invertebrate Taxonomy and its Applications Unit Group, Department of Biology, Faculty of Science, \\ Mahasarakham University, Kantarawichai district, MahaS arakham - 44150, Thailand \\ 2Plant and Invertebrate Taxonomy and its Applications Unit Group, Walairukhavej Botanical Research Institute, \\ Mahasarakham University, Kantarawichai district, Maha Sarakham - 44150, Thailand \\ ${ }^{3}$ Brio Garden, 53 M.5 Ban Mai Village, Phikun Ok, Ban Na district, Nakhon Nayok - 26110, Thailand \\ ${ }^{\star}$ E-mail: surapon.s@msu.ac.th
}

\begin{abstract}
Cornukaempferia argentifolia, a new species of Zingiberaceae from northern Thailand, is described and illustrated along with photographs, notes on its distribution, ecology, and IUCN conservation status. An identification key to the species of Cornukaempferia Mood \& K.Larsen in Thailand and a distribution map are also presented.
\end{abstract}

Keywords: Cornukaempferia kamolwaniae, Cornukaempferia larsenii, Endangered, Phitsanulok province.

\section{Introduction}

Cornukaempferia Mood \& K.Larsen was first established as a new genus of Zingiberaceae from Thailand with C. aurantiiflora Mood \& K.Larsen as its type (Mood \& Larsen, 1997). Subsequently, a second species, C. longipetiolata Mood \& K.Larsen was published in 1999 (Mood \& Larsen, 1999). The latter has since been found to be quite common in the mountains of Phitsanulok province near the border of Thailand and Laos. A third species $C$. larsenii P.Saensouk was published in 2007, which was found in Phu Ruea and Na Haeo national parks, Loei province, Thailand (Saensouk et al., 2007), and also in Laos (Rakarcha et al., 2020). In 2019, two additional species from northern Thailand, C. chayanii Yupparach \& Wongsuwan and $C$. kamolwaniae Picheans., Yupparach \& Wongsuwan were published (Yupparach et al., 2019).

Received: 25.01.2021; Revised \& Accepted: 30.05 .2021

Published Online: 31.12.2021
The authors are revising the genus Cornukaempferia for the Flora of Thailand project and during exploration of the diversity of the Zingiberaceae in Thailand, a morphologically distinct species of Cornukaempferia was collected. It did not match with any existing taxa, and is hence described, illustrated, and photographed below as a species new to science. A key to the species of Cornukaempferia in Thailand is provided for facilitating their identification.

\section{Materials and Methods}

Plant materials were collected from the field in Chattrakarn district, Phitsanulok province, northern Thailand, between 2018 and 2020. Living specimens and spirit specimens were used for making detailed morphological measurements. The living specimens have been planted at the Brio Garden herbarium and spirit-preserved specimens deposited at the KKU herbarium and Brio Garden herbarium. The living specimens were used for comparison and verification compared to living and dried specimens in herbaria in Thailand (BK!, BKF!, KKU!, QBG!) including the cultivated species at Brio Garden, and the protologues of all species in Cornukaempferia (Mood \& Larsen, 1997; Mood \& Larsen, 1999; Saensouk et al., 2007; Yupparach et al., 2019). A preliminary conservation assessment was made, based on the guidelines of IUCN Red List Categories (IUCN, 2019). Altitude determination from sea level was obtained from recorded tracks in the 'View-Ranger' application (Augmentra Ltd., Cambridge, UK). 


\section{Taxonomic Treatment}

Cornukaempferia argentifolia Boonma \& Saensouk, sp.nov.
Figs. $1 \& 2$
Similar to Cornukaempferia larsenii P.Saensouk but differs by its leaves (adaxially silver without markings $v s$. green with few silvery markings adaxially), bracts
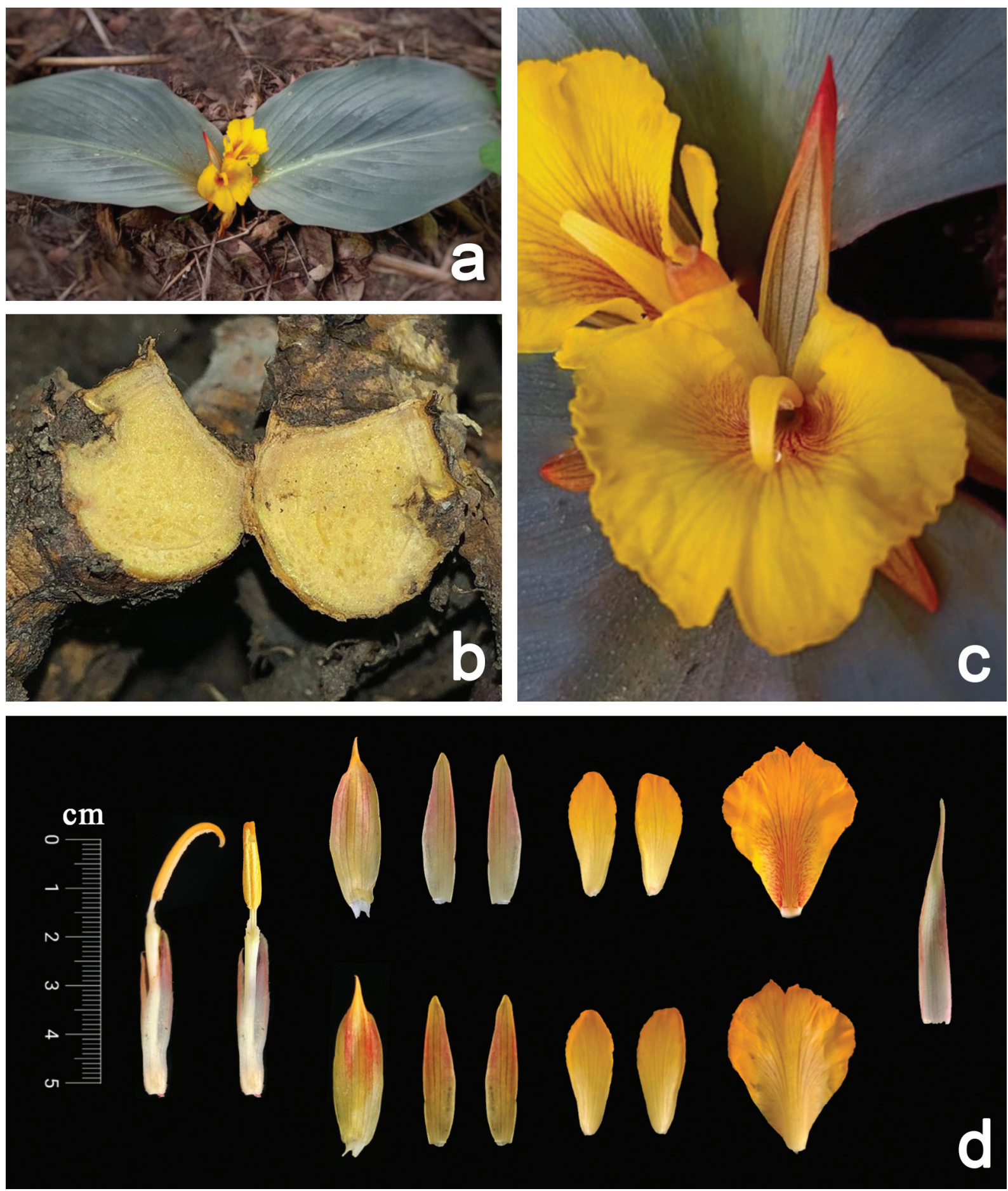

Fig. 1. Cornukaempferia argentifolia Boonma \& Saensouk: a. Habit; b. Cross-section of rhizome; c. Flowers; d. (from left to right) side view and front view of anther with calyx, (upper row) inner side of dorsal corolla lobe, lateral corolla lobes, lateral staminodes, and upper side of the labellum, (lower row) outer side of dorsal corolla lobe, lateral corolla lobes, lateral staminodes, lower side of the labellum, and bract (from $T$. Boonma 23; photos by T. Boonma). 


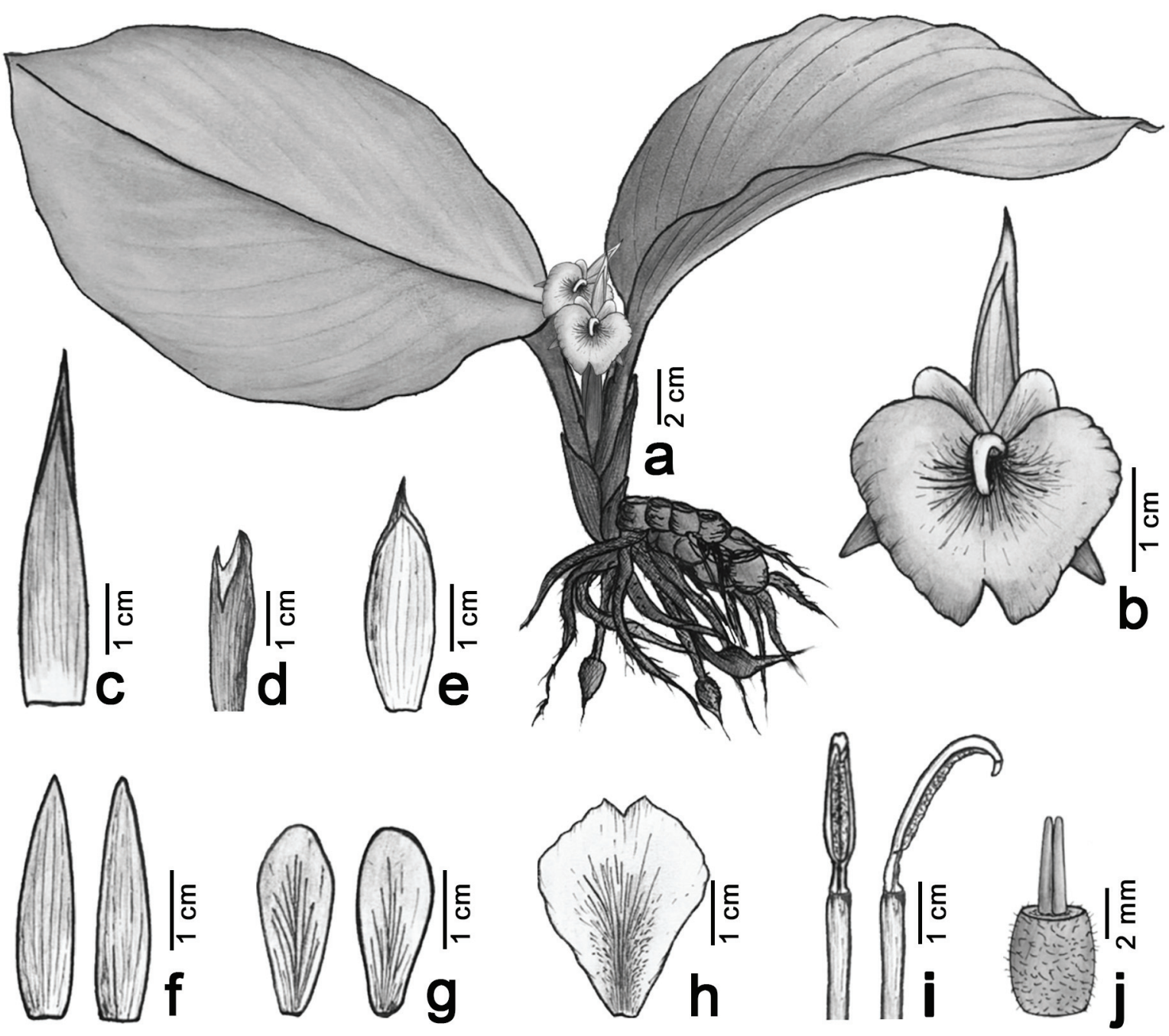

Fig. 2. Cornukaempferia argentifolia Boonma \& Saensouk: a. Habit with flowers and underground parts; b. Front view of flower; c. Bract; d. Calyx; e. Dorsal corolla lobe; f. Lateral corolla lobes; g. Lateral staminodes; h. Labellum; i. Front and side view of anther; j. Ovary with epigynous glands (from T. Boonma 23; drawn by T. Boonma).

(glabrous vs. sparsely hairy), corolla tube (finely hairy vs. glabrous), labellum (obovate with emarginate apex $v$ s. campanuloid with rounded apex) and filaments (finely hairy $v s$. glabrous).

Type: THAILAND, Phitsanulok province,

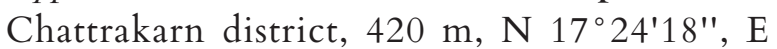
$100^{\circ} 45^{\prime} 00^{\prime}$, 21.07.2019, T. Boonma 23 (holo KKU!; iso QBG!, BKF!, BK!).

Rhizomatous herbs, up to $20 \mathrm{~cm}$ tall. Rhizome subglobose to obovoid, sympodial, slightly aromatic, with 2 layers, both layers yellow (when fresh) and brownish (when dry), 1-1.8 cm diam. Roots fascicle tuberous with fibrous roots; tubers ellipsoid, 1-1.5 mm diam. Cataphylls 1-2, 6-9 cm long, apex acute to slightly mucronate with ciliate margins, sparsely hairy, reddish-brown with white at the base, decaying while the pseudo-stem grows up. Leafsheaths distichous, 7-8 cm long, finely hairy, reddish-brown mixed with green. Ligules membranous, c. $2.5 \times 6-7 \mathrm{~mm}$, apex rounded to truncate, glabrous, translucent white. Leaves 2-3; petioles $2.5-4.5 \mathrm{~cm}$ long, finely hairy, reddishbrown; lamina ovate, asymmetrical 23-27 × 12-15 $\mathrm{cm}$, apex mucronate, base attenuate, margins entire, translucent red, adaxially silver without marking, midrib lighter silver, sometimes with reddish tinge at midrib, clearly embossed veins, abaxially surface 
red, both surfaces pubescent. Inflorescence terminal. Peduncles very short, less than $1 \mathrm{~cm}$ long. Bract lanceolate, $4.5-5 \times c .1 \mathrm{~cm}$, apex acute, glabrous. Flowers 2 or 3 per inflorescence, c. $4.7 \mathrm{~cm}$ long; calyx tubular, $3.3-3.5 \mathrm{~cm}$ long, apex bi-lobed with the deepest incision $c .1 .5 \mathrm{~cm}$, sparsely hairy, translucent white to pale yellow with red tinge; corolla tube $2.9-3.2 \times 0.23-0.25 \mathrm{~cm}$ diam., finely hairy, white to pale yellowish-white; dorsal corolla lobe lanceolate, c. $3.4 \times 1.1 \mathrm{~cm}$, apex mucronate with slightly hooded, glabrous on both surfaces, yellow with red tinge or yellow with red apex; lateral corolla lobes 2 , lanceolate, $c .3 \times 0.7 \mathrm{~cm}$, apex acute, glabrous on both surfaces, yellow with red tinge. Staminodes narrowly obovate, c. $2.5 \times 1 \mathrm{~cm}$, apex rounded to obtuse, glabrous, yellowish orange gradually fade to pale yellow at base. Labellum obovate, $3.4-3.6 \times 2.6-2.8 \mathrm{~cm}$, apex emarginate (incision $5-6 \mathrm{~mm}$ ), with finely undulate margins, glabrous on both surfaces, upper surface yellowish orange gradually fade to pale yellow at the base with red veins from base to half of the length, lower surface yellowish orange gradually fade to pale yellow without red veins. Stamen $22.8-23.2 \mathrm{~mm}$ long; filament c. $3.8 \times 2 \mathrm{~mm}$, pale yellowish white, finely hairy; anther $2.8-3 \times 0.2-0.3 \mathrm{~cm}$, yellow, opening longitudinally, connective produced into a long, narrow, forwards curved crest, pubescent. Epigynous glands 2, c. $4 \mathrm{~mm}$ long, c. $0.6 \mathrm{~mm}$ diam., yellow, apex blunt. Ovary ellipsoid-cylindrical, $c$. $3.6 \mathrm{~mm}$ long, c. $4.2 \mathrm{~mm}$ diam., pubescent; style white, glabrous; stigma pale yellow, c. $0.7 \mathrm{~mm}$ long,

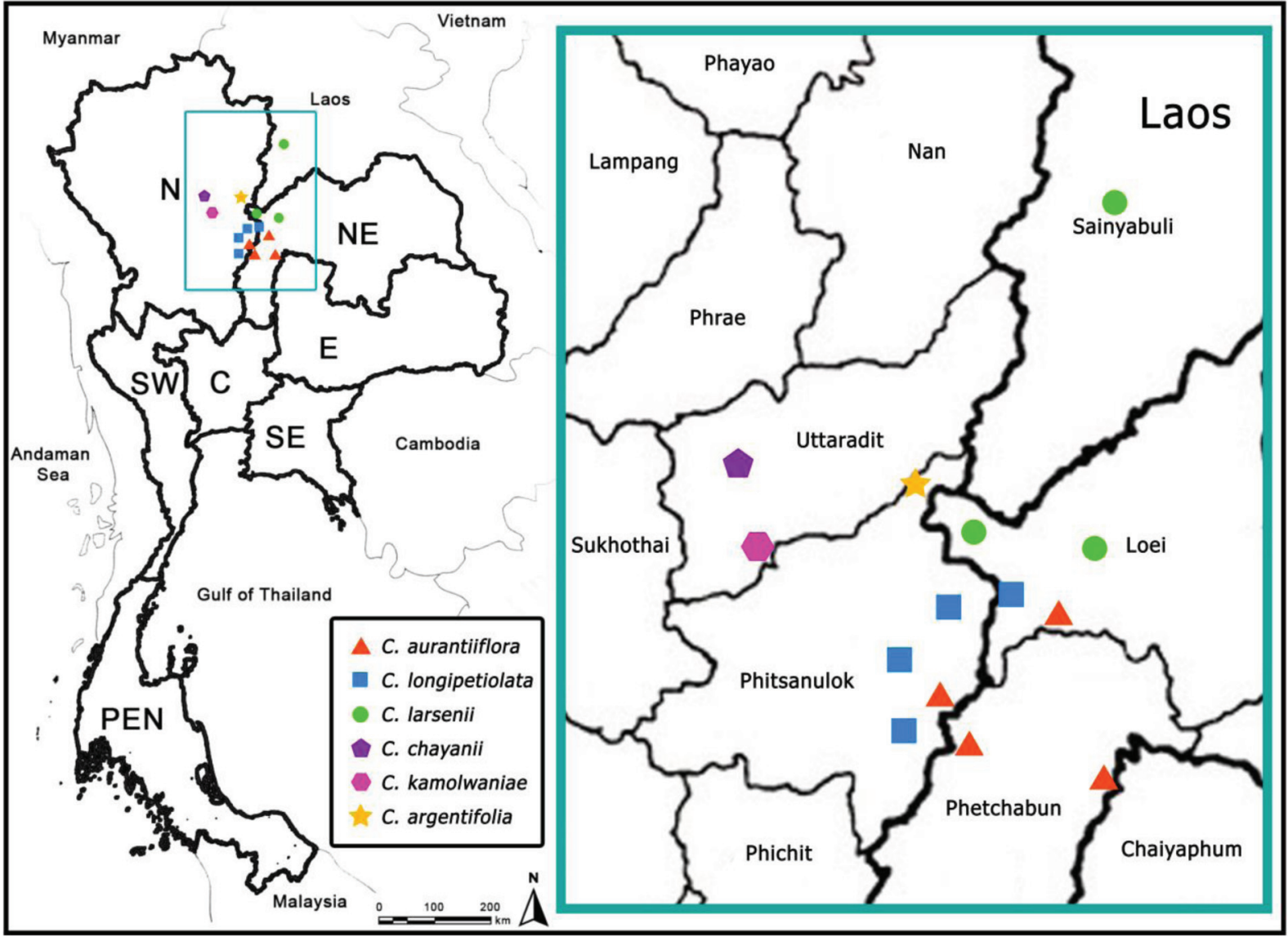

Fig. 3. Distribution map of species of Cornukaempferia Mood \& K.Larsen in Thailand and Laos. An enlarged view of the distribution area is on the right-hand side. The map of Thailand with the abbreviation of floristic regions and the enlarged view with the name of provinces, both were drawn in references to the map of Thailand after the "Flora of Thailand" Project which was published in "Gingers of Thailand"; abbreviation of regions: N = Northern; NE = Northeastern; E = Eastern; SW = Southwestern; C = Central; SE = Southeastern; PEN = Peninsular (Larsen \& Larsen, 2006). Each species distribution location is based on the protologue of all species in Cornukaempferia (Mood \& Larsen, 1997, 1999; Saensouk et al., 2007; Yupparach et al., 2019) and specimens deposit at QBG. 
c. $0.7 \mathrm{~mm} \times$ c. $1.4 \mathrm{~mm}$ wide, flatten-inverted cone, ciliate. Fruits not seen.

Common name: "Hazy" in reference to its silver leaves.

Flowering \& fruiting: Flowering from July to September. Flowers open in the morning and last a single day. Leafy shoot emerging in May and dormancy begins in November. Fruiting not observed.

Habitat: Occurring at elevations of 420 meters above sea level, growing in sandy loam soil, moist and close to the watercourse in a deciduous forest.

Distribution: Hitherto endemic to northern Thailand (Fig. 3).

Etymology: The specific epithet "argentifolia" is derived from two Latin words, "argenti" meaning "silver" and "folia" meaning "leaves" and refers to its silvery leaves.

Specimens examined: THAILAND, [cultivated] Nakhon Nayok province, Ban Na district, 53 M.5 Ban Mai village, Phikun Ok, 21.07.2019, T. Boonma 231 (Brio Garden).

Conservation status: Villagers who live close to the locality report that C. argentifolia argentifolia has been continuously exploited and removed from its habitat for many years. According to our survey since 2018, we found only one locality with mature individuals of less than 1,000. The living plants of this species were also sold in online media and exported overseas too. Due to its popularity, and market demand this species was continuously smuggled out of the forest, such that it is prone to be negatively affected by human activities more than by natural droughts within a very short time and has an uncertain future. However, further fieldwork is needed to assess changes in population distribution and abundance of this taxa. According to IUCN Criteria, (IUCN, 2019), the species falls under the category Data Deficient (DD).

Notes: The coloured silver leaves of C. argentifolia makes it easily distinguishable from other species in the genus. It is mostly similar to C. larsenii in having equally sized epigynous glands ( $4 \mathrm{~mm}$ long), glabrous staminodes, and labellum on both surfaces but differs in having leaves adaxially silver above and reddish below, glabrous bracts, finely hairy corolla tube, obovate labellum, finely hairy filaments, bi-lobed calyx apex, and a yellow rhizome with yellow core. While C. larsenii has green leaves with few silvery markings above, sparsely hairy bracts, glabrous corolla tube, campanuloid labellum, glabrous filaments, tridentate calyx apex, and a yellowish white rhizome with yellow core. Cornukaempferia argentifolia is also similar to C. kamolwaniae, but can be readily distinguished by its silver coloured leaves. A morphological comparison of C. argentifolia and its allied species is given in Table 1, and a key to the species of Cornukaempferia is also provided for facilitating their identification.

\section{Key to species of Cornukaempferia}

1. Layers of rhizome in cross-section 3 C. longipetiolata

1. Layers of rhizome in cross-section 2 ........... 2

2. Labellum and staminodes hairy on both surfaces; leaf adaxially green without silvery markings

... 3

2. Labellum and staminodes glabrous on both surfaces; leaf adaxially silver or green with silvery markings

... 4

3. Corolla tube pubescent; filament $2-5 \mathrm{~mm}$ long C. chayanii

3. Corolla tube glabrous; filament 7-9 mm long C. kamolwaniae

4. Bracts glabrous; corolla tube finely hairy; filament finely hairy; leaf adaxially silver without marking C. argentifolia

4. Bracts pubescent; corolla tube glabrous; filament glabrous; leaf adaxially green with silvery markings .... 5

5. Leaf abaxially purple, adaxially green with numerous silvery markings; petioles $5-11 \mathrm{~cm}$ long ........................................ C. aurantiiflora

5. Leaf abaxially green, adaxially green with few silvery markings; petioles $3-8 \mathrm{~cm}$ long

C. larsenii 
Table 1. Morphological comparison of Cornukaempferia argentifolia and its allied species

\begin{tabular}{|c|c|c|c|}
\hline Characters & $\begin{array}{l}\text { C. argentifolia Boonma } \\
\text { \& Saensouk }\end{array}$ & C. larsenii P.Saensouk & $\begin{array}{l}\text { C. kamolwaniae Picheans., } \\
\text { Yupparach \& Wongsuwan }\end{array}$ \\
\hline Leafless sheath & $\begin{array}{l}1-2 \text {, reddish-brown, } \\
\text { white at base }\end{array}$ & 3 , green to reddish & 3 , white-greenish or reddish \\
\hline Leaves & $\begin{array}{l}\text { Asymmetrical ovate, } \\
23-27 \times 12-15 \mathrm{~cm}\end{array}$ & $\begin{array}{l}\text { Broadly ovate to sub-orbicular, } \\
17-26 \times 11.8-17 \mathrm{~cm}\end{array}$ & $\begin{array}{l}\text { Broadly ovate to broadly } \\
\text { ovate-elliptic, } \\
19.3-22.2 \times 12.1-14.0 \mathrm{~cm}\end{array}$ \\
\hline Leaf adaxial surface & $\begin{array}{l}\text { Silver without marking, } \\
\text { midrib lighter silver, } \\
\text { sometimes with reddish } \\
\text { tinge at midrib }\end{array}$ & $\begin{array}{l}\text { Green with a few silvery } \\
\text { markings, midrib green }\end{array}$ & $\begin{array}{l}\text { Green without silvery } \\
\text { markings, midrib green }\end{array}$ \\
\hline $\begin{array}{l}\text { Leaf abaxial surface } \\
\text { colour }\end{array}$ & Red & Green & Greenish or purple greenish \\
\hline Leaf apex & Mucronate & Acute & Acute \\
\hline Number of flowers & $2-3$ & $3-5$ & $2-5$ \\
\hline Bracts & Lanceolate, glabrous & Ovate, sparsely hairy & $\begin{array}{l}\text { Lanceolate to broadly } \\
\text { lanceolate, glabrous with } \\
\text { pubescent apex }\end{array}$ \\
\hline Calyx & $\begin{array}{l}\text { Translucent white to pale } \\
\text { yellow with red tinge, } \\
\text { apex bi-lobed }\end{array}$ & White, apex tridentate & $\begin{array}{l}\text { Greenish, sparsely pubescent, } \\
\text { apex bi(-tri)-dentate }\end{array}$ \\
\hline Corolla tube & $\begin{array}{l}2.9-3.2 \mathrm{~cm} \text { long, white } \\
\text { to pale yellowish white, } \\
\text { finely hairy }\end{array}$ & $\begin{array}{l}2.0-3.2 \mathrm{~cm} \text { long, white, } \\
\text { glabrous }\end{array}$ & $\begin{array}{l}2.5-3.9 \mathrm{~cm} \text { long, white, } \\
\text { glabrous }\end{array}$ \\
\hline Corolla lobes & $\begin{array}{l}\text { Yellow with red tinge } \\
\text { or yellow with red apex }\end{array}$ & Red & Yellow reddish \\
\hline Dorsal corolla lobe & c. $3.4 \mathrm{~cm}$ long, glabrous & c. $3 \mathrm{~cm}$ long, glabrous & $\begin{array}{l}3.8-4.2 \mathrm{~cm} \text { long, } \\
\text { sparsely hairy }\end{array}$ \\
\hline Staminodes & Glabrous & Glabrous & Pubescent \\
\hline Labellum & $\begin{array}{l}3.4-3.6 \times 2.6-2.8 \mathrm{~cm} \text {, } \\
\text { obovate, glabrous }\end{array}$ & $\begin{array}{l}3-3.5 \times 2.5-3 \mathrm{~cm}, \\
\text { campanuloid, broadly } \\
\text { sub-orbicular, glabrous }\end{array}$ & $\begin{array}{l}3.4-4.4 \times 2.7-3.4 \mathrm{~cm}, \\
\text { broadly obovate, } \\
\text { pubescent }\end{array}$ \\
\hline Labellum-apex & $\begin{array}{l}\text { Emarginate, each lobe acute, } \\
\text { incision 5-6 } \mathrm{mm} \text { long }\end{array}$ & Rounded & $\begin{array}{l}\text { Rounded, slightly } \\
\text { emarginate, incision } 2-3 \mathrm{~mm}\end{array}$ \\
\hline Filament & $\begin{array}{l}\text { c. } 3.8 \mathrm{~mm} \text { long, pale } \\
\text { yellowish-white, } \\
\text { outer finely hairy }\end{array}$ & $\begin{array}{l}\text { c. } 5 \mathrm{~mm} \text { long, yellow, } \\
\text { outer glabrous }\end{array}$ & $\begin{array}{l}\text { 7-9 mm long, yellow, } \\
\text { outer glabrous }\end{array}$ \\
\hline Epigynous glands & $4 \mathrm{~mm}$ long & $4 \mathrm{~mm}$ long & $1-2 \mathrm{~mm}$ long \\
\hline
\end{tabular}

\section{Acknowledgments}

This research project was financially supported by Mahasarakham University 2021. We would like to thanks Walairukhavej Botanical Research Institute, Mahasarakham University, Brio Botanical Research Garden (Brio Garden), and our family for their facilities during this study. Many thanks to Dr.
Jolyon Dodgson (UK) for language editing and suggestions to improve the manuscript.

\section{Literature Cited}

IUCN 2019. Guidelines for Using the IUCN Red List Categories and Criteria. Version 14 Prepared by the Standards and Petitions Committee. Available at: 
http://www.iucnredlist.org/documents/RedList Guidelines. pdf (Accessed on 19.06.2021)

LARSEN K. \& S.S. LARSEN 2006. Gingers of Thailand. Queen Sirikit Botanic Garden, The Botanical Garden Organisation, Chiang Mai.

MOOD J. \& K. LARSEN 1997. Cornukaempferia, a new genus of Zingiberaceae from Thailand. Natural History Bulletin of the Siam Society 45: 217-221.

MOOD J. \& K. LARSEN 1999. New to cultivation: the genus Cornukaempferia in Thailand with description of a second species. The New Plantsman 6: 196-205.

RAKARCHA S., MAKNOI C., SAENSOUK P. \& S. SAENSOUK 2020. Cornukaempferia larsenii (Zingiberaceae)
- A new record for Lao PDR. The Journal of Japanese Botany 95(4): 235-237.

SAENSOUK P., THEERAKULPISUT P. \& P. CHANTARANOTHAI 2007. Cornukaempferia larsenii sp. nov. (Zingiberaceae): a new species from Thailand. The Natural History Journal of Chulalongkorn University 7(2): 115-119.

YUPPARACH P., WONGSUWAN P., PHOKHAM B., SANGNARK S. \& C. PICHEANSOONTHON 2019. Two new species of Cornukaempferia (Zingiberaceae) from Thailand. The Journal of Japanese Botany 94(2): 82-89. 